\title{
Host Range Investigations of New, Undescribed, and Common Phytophthora spp. Isolated from Ornamental Nurseries in Minnesota
}

\author{
B. W. Schwingle and R. A. Blanchette, Department of Plant Pathology, University of Minnesota, 495 Borlaug Hall, \\ 1991 Upper Buford Circle, St. Paul, MN 55108
}

\begin{abstract}
Schwingle, B. W., and Blanchette, R. A. 2008. Host range investigations of new, undescribed, and common Phytophthora spp. isolated from ornamental nurseries in Minnesota. Plant Dis. 92:642-647.

Eleven woody landscape plants commonly grown in the upper Midwestern United States were inoculated with up to three unnamed Phytophthora taxa (Phytophthora taxon Pgchlamydo, a Phytophthora alni-like isolate [Phytophthora MN14d], and Phytophthora sp. MN1) to explore their host ranges. In addition, $P$. cactorum, $P$. citricola, $P$. citrophthora, $P$. hedraiandra, and $P$. nicotianae were used to inoculate plants to further investigate the susceptibilities of plant genera previously found associated with these pathogens, to explore the susceptibility of important landscape plants (i.e., oak) to common ornamental Phytophthora spp., and to prove Koch's postulates. Koch's postulates were completed on fragrant sumac with P. citricola and P. nicotianae and on common lilac with $P$. citrophthora. A nonwound or wound inoculation technique were used to determine host susceptibility. Phytophthora sp. MN1 caused symptoms on American cranberrybush, bur and red oak, common lilac, fragrant sumac, Norway maple, and 'P.J.M.' rhododendron. The newly described organism $P$. hedraiandra caused disease on American cranberrybush, common lilac, red oak, and 'Snowdrift' crabapple. Fragrant sumac and common lilac generally were the most susceptible hosts to all Phytophthora spp. This study demonstrated that many ornamental Phytophthora pathogens have larger potential host ranges than previously known. The biology and ecology of $P$. hedraiandra and Phytophthora sp. MN1 must be further investigated, and methods for rapid identification should be developed.
\end{abstract}

The genus Phytophthora encompasses approximately 70 phytopathogenic species, and ornamental plants around the world are affected by diseases caused by these organisms (8). Leaf spots and lesions, dieback, cankers, wilt, and root rot are symptoms that develop on woody plants from infection by Phytophthora spp. (8). Among the most common Phytophthora pathogens of ornamental plants are Phytophthora cactorum, P. cinnamomi, $P$. citricola, $P$. citrophthora, and $P$. nicotianae $(10,18)$. Several new Phytophthora spp. have been discovered over the past 10 years $(5,13,22)$, and some of these, such as $P$. ramorum, have proven to be aggressive pathogens of both ornamentals and plants in native ecosystems $(17,22)$.

From 2003 to 2005 , P. ramorum surveys of diseased ornamentals took place throughout Minnesota, resulting in a study which reported the presence of many Phytophthora spp., but not $P$. ramorum, associated with disease in ornamental nurseries (20). Many of the plants from which the Phytophthora spp. were isolated were not

Corresponding author: R. A. Blanchette

E-mail: robertb@umn.edu

Accepted for publication 24 November 2007.

doi:10.1094/PDIS-92-4-0642

(C) 2008 The American Phytopathological Society previously reported as hosts. Also, Phytophthora isolates with different characteristics from known species were found, and these caused concern among growers and regulatory agencies for their potential as destructive agents in the natural landscape.

$P$. hedraiandra was one species found in the Minnesota survey that was new to North America (21). It is a recently described species that is morphologically similar to $P$. cactorum, $P$. idaei, and $P$. pseudotsugae (7). P. hedraiandra first was reported from the Netherlands (7) and subsequently was reported from Spain (19) and Italy (1) on Viburnum tinus and in Australia from soil (6).

Two other previously undescribed Phytophthora isolates that were found in the 2003-05 Minnesota surveys were designated Phytophthora sp. MN1 and Phytophthora sp. MN14d (20). Phytophthora sp. MN14d appears closely related to $P$. alni subsp. alni, which has killed European alder (Alnus glutinosa) across Europe $(2,11)$. Both of these isolates have raised concerns about the potential damage they may cause in the urban and forested landscapes of the United States.

The objectives of this study were to evaluate the pathogenicity of undescribed Phytophthora spp. and expand our knowledge of the host range for these and other Phytophthora spp. that were obtained during recent surveys in Minnesota.

\section{MATERIALS AND METHODS}

Phytophthora spp. and study plants. The Phytophthora isolates used for inoculations (Table 1) were isolated from diseased ornamental plants in various Minnesota nurseries between 2003 and 2005 (20).

Host plants that were inoculated are listed in Tables 1 and 2. Common lilac (Syringa vulgaris), fragrant sumac (Rhus aromatica), Norway maple (Acer platanoides 'Variegatum'), and 'Snowdrift' crabapple (Malus 'Snowdrift') were found in our previous study (20) to be associated with one of the Phytophthora isolates listed in Table 1; however, pathogenicity on those hosts had not been demonstrated. Therefore, we attempted to fulfill Koch's postulates on them with the respective Phytophthora spp. originally associated with them. V. trilobum was selected because we previously found a Viburnum sp. to be susceptible to $P$. cactorum, $P$. citricola, and P. hedraiandra (20). For the same reason, a spirea species was chosen to be inoculated with $P$. citricola and 'P.J.M.' rhododendron was selected to be inoculated with Phytophthora taxon Pgchlamydo. Frequently isolated ornamental Phytophthora spp. were tested on bur and northern red oak because the susceptibility of these abundant trees on the natural landscape is unknown.

Nothing is known of the host range of Phytophthora sp. MN14d and Phytophthora sp. MN1 and little is known of the host range of $P$. hedraiandra and Phytophthora taxon Pgchlamydo (3). To explore their host ranges, the abovementioned plants were used with these undescribed Phytophthora spp. in inoculation studies. Because Phytophthora sp. MN14d is similar to $P$. alni subsp. alni, European alder was inoculated with Phytophthora sp. MN14d so that the virulence of Phytophthora sp. MN14d could be compared with disease caused by $P$. alni subsp. alni.

All plants were field grown in commercial nurseries, transplanted while dormant into pots containing a mixture of coarse textured bark and peat moss, fertilized, and placed in a greenhouse. The ages of the plants were various and what were available when this project began: yew (Taxus $\times$ media) were 6 years old, P.J.M. rhododendron (Rhododendron P.J.M.) were 4 years old, oak were 2 years old, and the remaining plants were 1 year old. 
Inoculation methods. Two inoculation methods were employed. One method was a plant shoot dip into a zoospore suspension, as described by Hansen et al. (12), and the other was a stem wound inoculation. Table 2 shows the inoculation method used on each plant species. All Phytophthora isolates were grown on nonclarified V8 juice agar media amended with $\mathrm{CaCO}_{3}$ at $2 \mathrm{~g} /$ liter (8) prior to inoculation.

The first oak stem inoculation experiment took place approximately 2 weeks after leaves emerged (February 2006), and the experiment was replicated 1 month later in a second trial. Inoculated oak were placed in a $25^{\circ} \mathrm{C}$ growth chamber after inoculation. Stem and plant dip inoculation experiments on other plants were carried out approximately 4 weeks after leaves emerged. Those plants were placed in a greenhouse $\left(24\right.$ and $16^{\circ} \mathrm{C}$ day and night, respectively) after inoculation. These experiments were replicated 2.5 months later in a growth chamber $\left(21^{\circ} \mathrm{C}\right)$ to avoid unfavorable summer greenhouse temperatures and temperature fluctuations and to ensure that temperatures during the study would be similar those in the first trial.

Nonwound inoculations. Zoospores for the plant dip inoculations were produced by removing 10 to 20 colonized, $5-\mathrm{mm}$ agar plugs from the margins of 1-week-old colonies, which then were flooded in glass petri dishes with enough nonsterile $1.5 \%$ soil extract (14) to just cover the upper surfaces. To favor zoospore release from sporangia, the flooded plugs were held at room temperature for $48 \mathrm{~h}$, then at $4^{\circ} \mathrm{C}$ for $1 \mathrm{~h}$, and again at room temperature for at least another hour prior to inoculation. Zoospore concentration was quantified with a hemacytometer and adjusted to approximately 6,400 zoospores $/ \mathrm{ml}$ with sterile distilled water. This concentration was slightly above a concentration Hansen et al. (12) used in leaf dip inoculations, which proved effective at causing some necrosis in susceptible plants.

The terminal $12 \mathrm{~cm}$ of plant shoots were dipped into the zoospore suspension for 10 $\mathrm{s}$ and then covered with plastic bags. Plastic bags were removed 7 days post inoculation (dpi). Control plants were dipped into sterile water. Phytophthora isolates were reisolated from margins of diseased leaf or stem tissue 14 dpi using $\mathrm{P}_{10}$ ARP-CMA selective media (15), and symptoms and disease incidence (percentage of inoculated plants with symptoms) were recorded at the same time.

Each rhododendron-isolate interaction was replicated seven times and the remaining shrub species-isolate interactions were replicated five times. Tree species-isolate interactions were replicated four times for alder and maple and five times for crabapple. Inequality of experimental replication among different plant species was due to plant availability at the time the experiment was carried out.

Wound inoculations. Phytophthoracolonized agar plugs served as inocula for stem inoculations. They were removed with a 5-mm cork borer from the margins of 7-day-old cultures and placed under flap-like wounds on tree stems. Agar plugs with no fungal growth were placed under wounds on control tree stems. Wounds were made by cutting 7 to $15 \mathrm{~mm}$ down the stem into the cambium with a sterile scalpel and were situated approximately 5 $\mathrm{cm}$ above the root collar or graft site. The inoculated wounds were wrapped with sterile moist cheesecloth and Parafilm.

In the oak stem inoculation experiments, total lesion lengths and widths (including the original wound dimensions) were recorded 32 dpi and Phytophthora spp. were isolated from lesion margins 1 day later using $\mathrm{P}_{10} \mathrm{ARP}-\mathrm{CMA}$. In the alder, crabapple, and maple stem experiments, measurements of lesions and isolations of Phytophthora spp. occurred at 50 and $70 \mathrm{dpi}$ for the first and second trials, respectively.

All oak species-isolate interactions were replicated five times, and the other tree species-isolate interactions were replicated three, four, and five times for alder, maple, and crabapple, respectively. Again, inequality of experimental replication among different plant species was due to plant availability at the time the experiment was carried out.

For both inoculation methods, Phytophthora cultures from isolations were subcultured after 3 days onto V8 juice agar media and were identified 1 week after subculturing. Identifications were based on

Table 2. Scientific and common names of plants inoculated in this study and the inoculation method used

\begin{tabular}{lll}
\hline Scientific name & \multicolumn{1}{c}{ Common name } & Inoculation method \\
\hline Acer platanoides 'Variegatum' & Variegated Norway maple & Plant dip, stem wound \\
Alnus glutinosa & European alder & Plant dip, stem wound \\
Malus $\times$ 'Snowdrift' & 'Snowdrift' crabapple & Plant dip, stem wound \\
Quercus macrocarpa & Bur oak & Stem wound \\
Q. rubra & Northern red oak & Stem wound \\
Rhododendron 'P.J.M.' & 'P.J.M.' rhododendron & Plant dip \\
Rhus aromatica & Fragrant sumac & Plant dip \\
Spiraea sp. & Spirea & Plant dip \\
Syringa vulgaris & Common lilac & Plant dip \\
Taxus $\times$ media & Anglojapanese yew & Plant dip \\
Viburnum trilobum & American cranberrybush & Plant dip \\
\hline
\end{tabular}

Table 1. Phytophthora isolates and plant species used for the inoculations

\begin{tabular}{|c|c|c|c|c|}
\hline Isolate & $\begin{array}{l}\text { GenBank } \\
\text { accession } \\
\text { number }^{\mathrm{a}}\end{array}$ & Species & Original host and symptoms & Plants inoculated ${ }^{b}$ \\
\hline MN16HH & NA & Phytophthora cactorum & Viburnum prunifolium - dieback & Viburnum trilobum \\
\hline MN2FF & NA & P. citricola & Rhus aromatica, leaf lesions & Rhus aromatica* \\
\hline MN18HH & NA & P. citricola & V. prunifolium, leaf margin necrosis & Spiraea sp., V. trilobum \\
\hline MN3KK & NA & P. citrophthora & Syringa vulgaris, dieback & R. aromatica, S. vulgaris* \\
\hline MNT832003 & DQ139806 & P. hedraiandra & $\begin{array}{l}\text { Rhododendron sp., unknown } \\
\text { symptoms }\end{array}$ & Quercus macrocarpa, Q. rubra \\
\hline MN14FF & DQ486667 & P. hedraiandra & Viburnum trilobum, root rot & $\begin{array}{l}\text { Malus 'Snowdrift', Spiraea sp., S. vulgaris, } \\
\text { Taxus } \times \text { media, V. trilobum }\end{array}$ \\
\hline MN16JJ & DQ486670 & P. nicotianae & R. aromatica, dieback & Q. macrocarpa, Q. rubra, R. aromatica* \\
\hline $\mathrm{MN} 2 \mathrm{JJ}$ & NA & Phytophthora taxon Pgchlamydo & $\begin{array}{l}\text { Rhododendron 'Henry's Red', } \\
\text { leaf lesions }\end{array}$ & Rhododendron 'P.J.M.', Spiraea sp., S. vulgaris \\
\hline MN20FF & DQ486671 & Phytophthora taxon Pgchlamydo & Taxus sp., dieback & Q. macrocarpa, Q. rubra \\
\hline MN14d & DQ486658 & Unknown & Acer platanoides, leaf tip necrosis & $\begin{array}{l}\text { Acer platanoides 'Variegatum'*, Alnus glutinosa, } \\
\text { M. Snowdrift, } R \text {. P.J.M., T. × media }\end{array}$ \\
\hline MN1 & $\begin{array}{l}\text { DQ486672, } \\
\text { DQ486673 }\end{array}$ & Unknown & Malus $\times$ 'Snowdrift', leaf spots & $\begin{array}{l}\text { A. platanoides, A. glutinosa, M. Snowdrift*, } Q . \\
\text { macrocarpa, Q. rubra } R . \text { aromatica, } R \text {. P.J.M., } \\
\text { Spiraea sp., S. vulgaris, } T . \times \text { media, V. trilobum }\end{array}$ \\
\hline
\end{tabular}

${ }^{\mathrm{a}} \mathrm{NA}=$ sequences from isolates were not accessioned in GenBank.

b An asterisk following a species indicates that Koch's postulates were tested for that respective host and pathogen. 
morphological characteristics (sporangial shape and presence of papilla, presence of chlamydospores, and hyphal swellings, homothallic or heterothallic; 3,5,7,8) and DNA sequencing of the internal transcribed spacer (ITS) region of the rDNA (20). The ITS-1, 5.8S, and ITS-4 portions of the rRNA gene were amplified by polymerase chain reaction (PCR) using the universal primers ITS1 and ITS4. DNA sequencing of the PCR products was performed by the DNA Sequencing and Analysis Facility at the University of Minnesota. Complimentary DNA strands were aligned with ChromasPro (version 1.22; strands were matched to those in GenBank using BLASTn searches.

Data analysis. Stem inoculation trials were analyzed using the general linear model in SAS Analyst (version 9.1; SAS Institute Inc., Cary, NC). Lesion length data was transformed to fit a normal distribution and ensure a uniform variance between treatments. Multifactorial analyses of variance (ANOVA) were performed on transformed lesion length data. When the effect of all interactions with trial were not significant $(P>0.05)$, data from the two Technelysium Pty. Ltd.), and the consensus

trials were combined. ANOVA were used to determine whether host and Phytophthora isolate had an effect on lesion length and width. Tukey's studentized range (highly significant difference) test was employed for means comparisons, and means were deemed significantly different at the $P<0.05$ level.

\section{RESULTS}

Nonwound inoculations. The plant dip inoculations resulted in dieback and lesions on stems as well as leaf spots on many of the hosts (Table 3). Relative disease severity in both plant dip inoculation experiments was highest on common lilac infected by $P$. citrophthora and on fragrant sumac infected by $P$. citricola, $P$. citrophthora, and P. nicotianae (data not shown). Symptoms that were expressed on lilac and sumac in these interactions were dieback, leaf lesions, and defoliation, and they were present on all inoculated shoots 2 weeks after inoculation. Isolations of the respective Phytophthora spp. used in the inoculations were made and are indicated in Table 3. Phytophthora spp. were not isolated from control plants.

Table 3. Results from two dip inoculation trials showing disease incidence and symptoms.

\begin{tabular}{|c|c|c|c|c|}
\hline Phytophthora sp., host & $n$ & $\begin{array}{c}\text { Pathogen } \\
\text { reisolated }^{\mathrm{a}}\end{array}$ & $\begin{array}{c}\text { Disease } \\
\text { incidence }^{\mathrm{b}}\end{array}$ & Symptoms \\
\hline \multicolumn{5}{|l|}{ Phytophthora cactorum } \\
\hline Viburnum trilobum & 10 & Yes & 70 & Dieback, leaf spots \\
\hline \multicolumn{5}{|l|}{ P. citricola } \\
\hline Spiraea sp. & 10 & Yes & 50 & Leaf lesions \\
\hline Rhus aromatica & 10 & Yes* & 100 & Dieback, leaf lesions \\
\hline V. trilobum & 10 & No & 10 & Leaf margin necrosis \\
\hline \multicolumn{5}{|l|}{ P. citrophthora } \\
\hline R. aromatica & 10 & Yes* & 100 & Dieback, leaf lesions \\
\hline Syringa vulgaris & 10 & Yes* & 100 & Dieback, leaf lesions, defoliation \\
\hline \multicolumn{5}{|l|}{ P. hedraiandra } \\
\hline Malus $\times$ 'Snowdrift' & 8 & Yes* & 100 & Leaf spots \\
\hline Spiraea sp. & 10 & No & 50 & Leaf spots \\
\hline S. vulgaris & 10 & Yes & 90 & Leaf tip necrosis \\
\hline Taxon $\times$ media & 10 & No & 0 & $\mathrm{n} / \mathrm{a}$ \\
\hline V. trilobum & 10 & Yes* & 70 & Leaf lesions \\
\hline \multicolumn{5}{|l|}{ P. nicotianae } \\
\hline R. aromatica & 10 & Yes* & 100 & Dieback, leaf spots \\
\hline \multicolumn{5}{|c|}{ Phytophthora taxon Pgchlamydo } \\
\hline Rhododendron 'P.J.M.' & 14 & No & 21 & Leaf spots \\
\hline Spiraea sp. & 10 & Yes & 50 & Leaf spots \\
\hline S. vulgaris & 10 & Yes & 100 & Leaf blotches \\
\hline \multicolumn{5}{|l|}{ Phytophthora sp. MN14d } \\
\hline Acer platanoides & 8 & No & 13 & Leaf spots \\
\hline Alnus glutinosa & 6 & No & 38 & Leaf spots \\
\hline Malus $\times$ 'Snowdrift' & 9 & No & 0 & $\mathrm{n} / \mathrm{a}$ \\
\hline Rhododendron 'P.J.M.' & 13 & No & 0 & $\mathrm{n} / \mathrm{a}$ \\
\hline Taxon $\times$ media & 10 & No & 0 & $\mathrm{n} / \mathrm{a}$ \\
\hline \multicolumn{5}{|l|}{ Phytophthora sp. MN1 } \\
\hline Acer platanoides & 8 & No & 25 & Leaf blotches \\
\hline Alnus glutinosa & 6 & No & 50 & Leaf spots \\
\hline Malus $\times$ 'Snowdrift' & 10 & No & 0 & $\mathrm{n} / \mathrm{a}$ \\
\hline Rhododendron 'P.J.M.' & 14 & Yes & 36 & Dieback, leaf lesions \\
\hline Rhus aromatica & 10 & Yes* & 90 & Leaf lesions \\
\hline Spiraea sp. & 10 & No & 50 & Leaf lesions \\
\hline S. vulgaris & 10 & Yes & 70 & Leaf spots \\
\hline Taxon $\times$ media & 10 & No & 0 & $\mathrm{n} / \mathrm{a}$ \\
\hline V. trilobum & 10 & Yes & 40 & Leaf lesions \\
\hline
\end{tabular}

${ }^{a}$ An asterisk indicates that the Phytophthora sp. was isolated in both experiments.

${ }^{\mathrm{b}}$ Disease incidence is the percentage of respective inoculated host plants showing disease symptoms. Both dip inoculation experiments were combined for this data.
Koch's postulates were fulfilled on the fragrant sumac- $P$. citricola and $-P$. nicotianae interactions as well as on the common lilac-P. citrophthora interaction. Symptoms from these interactions after dipping the shoots in a zoospore suspension (Table 3) were identical to symptoms found with the initial associations between these respective organisms (Table 1).

Wound inoculations. Lesion length data from both trials in the bur and red oak experiments were combined because the trial made no significant difference. The mean lesion lengths on bur oak and red oak caused by the four Phytophthora spp. are presented in Figure 1. Bur and red oak differed in their susceptibility to the Phytophthora spp. Specifically, P. hedraiandra, P. nicotianae, and Phytophthora taxon Pgchlamydo caused significantly longer lesions $(P<0.05)$ on red oak than on bur oak. On bur oak, Phytophthora sp. MN1, $P$. nicotianae, and Phytophthora taxon Pgchlamydo girdled trees significantly more than the width of the control wounds and, on red oak, P. nicotianae and Phytophthora taxon Pgchlamydo, girdled trees significantly more than the width of control wounds (data not shown). The respective Phytophthora spp. were isolated from each host-isolate combination, demonstrating the potential for these Phytophthora spp. to cause stem lesions on northern red and bur oak.

Lesion length data from both trials in the Norway maple and European alder experiments also were combined because the trial had no significant effect on lesion length $(P=0.7387$ and $P=0.1664$, respectively; Fig. 2). The trial did have a significant effect on Snowdrift crabapple lesion lengths $(P=0.0013)$; therefore, lesion length data from the two crabapple trials were not combined (Fig. 3). The respective Phytophthora spp. were isolated from each host-isolate combination, demonstrating potential stem pathogenicity, except that Phytophthora sp. MN14d was not isolated from European alder and Snowdrift crabapple.

\section{DISCUSSION}

We tested the susceptibility of 11 hosts to selected Phytophthora spp. in this study, and some of these hosts had no prior association with the potential pathogens. This is the first report demonstrating the potential pathogenicity of Phytophthora sp. MN1 and Phytophthora sp. MN14d on Norway maple; $P$. hedraiandra, Phytophthora sp. MN1, and Phytophthora sp. MN14d on Snowdrift crabapple; $P$. hedraiandra, $P$. nicotianae, Phytophthora taxon Pgchlamydo, and Phytophthora sp. MN1 on bur and northern red oak; Phytophthora sp. MN1 on rhododendron; $P$. citrophthora and Phytophthora sp. MN1 on fragrant sumac; P. citricola and Phytophthora taxon Pgchlamydo on spirea; $P$. hedraiandra, Phytophthora taxon Pgchla- 
mydo, and Phytophthora sp. MN1 on common lilac; and $P$. cactorum, $P$. hedraiandra, and Phytophthora sp. MN1 on American cranberrybush. The aggressiveness of Phytophthora sp. MN1 on stems of Snowdrift crabapple was low, because the mean lesion length it caused in both trials was either less than or not significantly different from the control mean wound length. However, it was reisolated and, therefore, was able to survive in Malus stem tissue.

This is the first report of completion of Koch's postulates for $P$. citricola and $P$. nicotianae with fragrant sumac and $P$. citrophthora with common lilac. In a previous study (20), P. citricola was associated with leaf lesions on fragrant sumac, $P$. nicotianae was associated with dieback of fragrant sumac, and $P$. citrophthora was associated with dieback of common lilac. In our present study, these three Phytophthora spp. caused identical symptoms on these respective host plants, and they were isolated from symptomatic tissue.

In this study, we demonstrated that a wide variety of Phytophthora spp. could cause dieback and leaf necroses on fragrant sumac. This suggests that fragrant sumac is highly susceptible to infection by Phytophthora spp. and, therefore, ornamental growers should be made aware of disease management strategies they can use to minimize disease on this host caused by Phytophthora spp. P. ramorum is the only other Phytophthora sp. known to be pathogenic on Rhus (i.e., R. diversiloba) (12).

Common lilac was another host that proved susceptible to all Phytophthora spp. tested. Disease severity on lilac was not as great, in general, as that on fragrant sumac, but it was greater than on other hosts (data not shown). Common lilac was reported to be highly susceptible to $P$. citrophthora, among other Phytophthora spp. (17), and this current project supports that finding. However, the P. citrophthora isolate used by Linderman et al. (17) was isolated originally from Rhododendron sp., and that is why this is the first study fulfilling Koch's postulates for $P$. citrophthora with common lilac.

Another species proven in this study to be a potential leaf pathogen of lilac was Phytophthora taxon Pgchlamydo. Its potential pathogenicity on leaves of spirea also was demonstrated, although it produced low disease incidence and severity on that host. Other hosts associated with this undescribed species are Abies procera, Alnus glutinosa, A. incana, Prunus sp., and Pseudotsuga menziesii $(3,4,16)$.

New hosts of Phytophthora hedraiandra have been reported recently $(1,19,20)$, and our study expands knowledge of its host range. The $P$. hedraiandra isolate we utilized in the nonwound inoculations was isolated from root tissue of an American cranberrybush exhibiting dieback symp- toms. $P$. hedraiandra caused leaf lesions to develop on this host. In addition to the genus Viburnum, our results confirm that other genera are also likely hosts of $P$. hedraiandra, including Syringa, Malus, and Quercus. P. cactorum is closely related to $P$. hedraiandra (7), and $P$. cactorum also has been reported to be pathogenic on $S$. vulgaris, Malus spp., and Quercus spp. (9).

Isolate Phytophthora sp. MN14d was first referred to as Unknown 2 (20). It is morphologically similar to $P$. alni but its identity remains ambiguous, because the
ITS rDNA sequence of this isolate does not match that of $P$. alni (20). Instead, it more closely matches ITS sequences of $P$. fragariae var. rubi and $P$. cambivora (20). This study showed that Norway maple is a potential host of Phytophthora sp. MN14d. $P$. cambivora is a known pathogen of Norway maple (9) and, because Phytophthora sp. MN14d is closely related, it was not surprising that it was virulent on Norway maple stems. Likewise, the potential pathogenicity of Phytophthora sp. MN14d on stems of Snowdrift crabapple was dem-
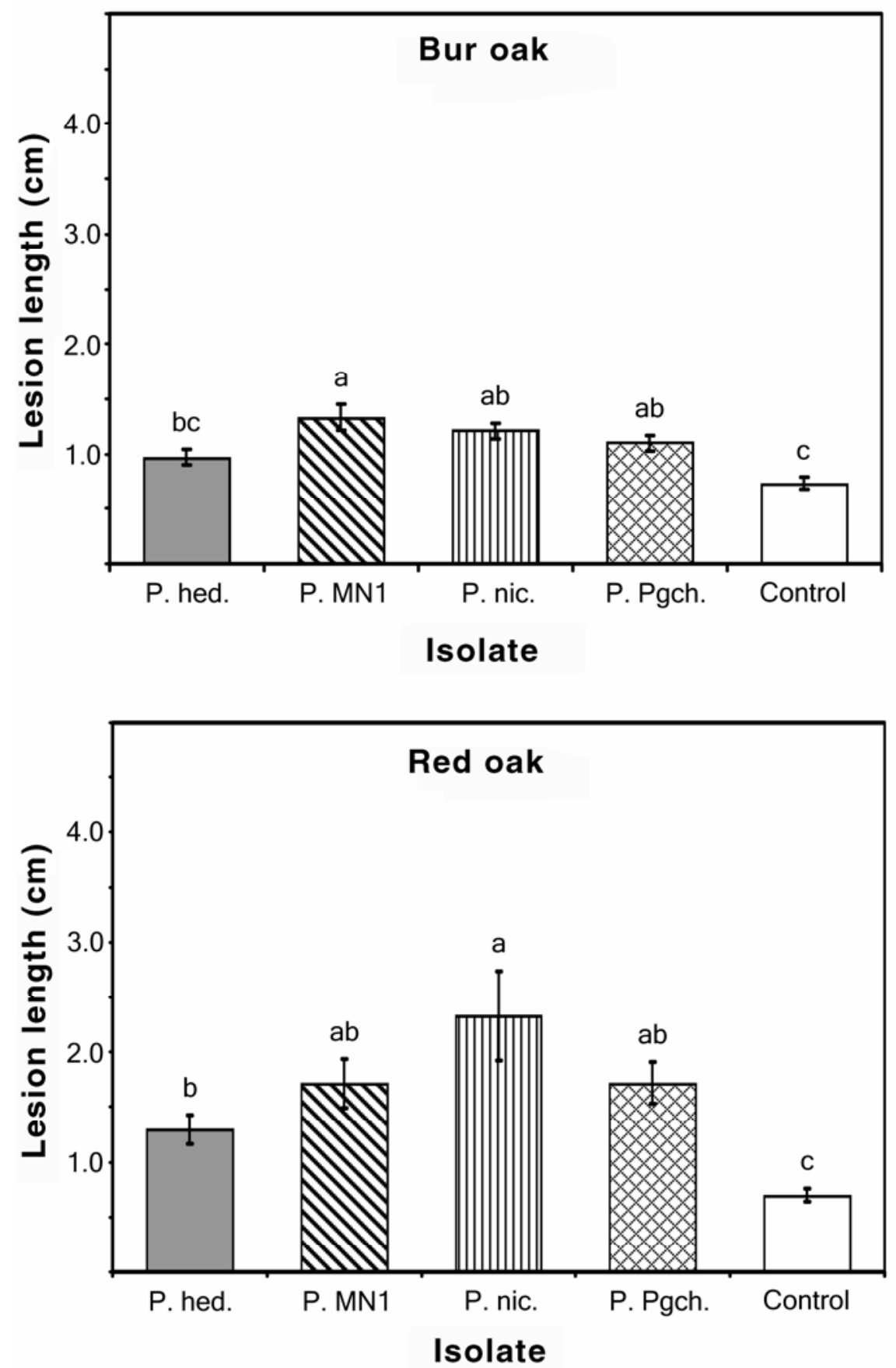

Fig. 1. Mean stem lesion lengths caused by Phytophthora hedraiandra (P. hed.), Phytophthora sp. MN1 (P. MN1), P. nicotianae (P. nic.), and Phytophthora taxon Pgchlamydo (P. Pgch.) and control mean wound lengths on bur oak and red oak. Bars represent standard errors, and different letters represent significantly different $(P<0.05)$ subgroups as indicated by Tukey's studentized range (highly significant difference) test. 

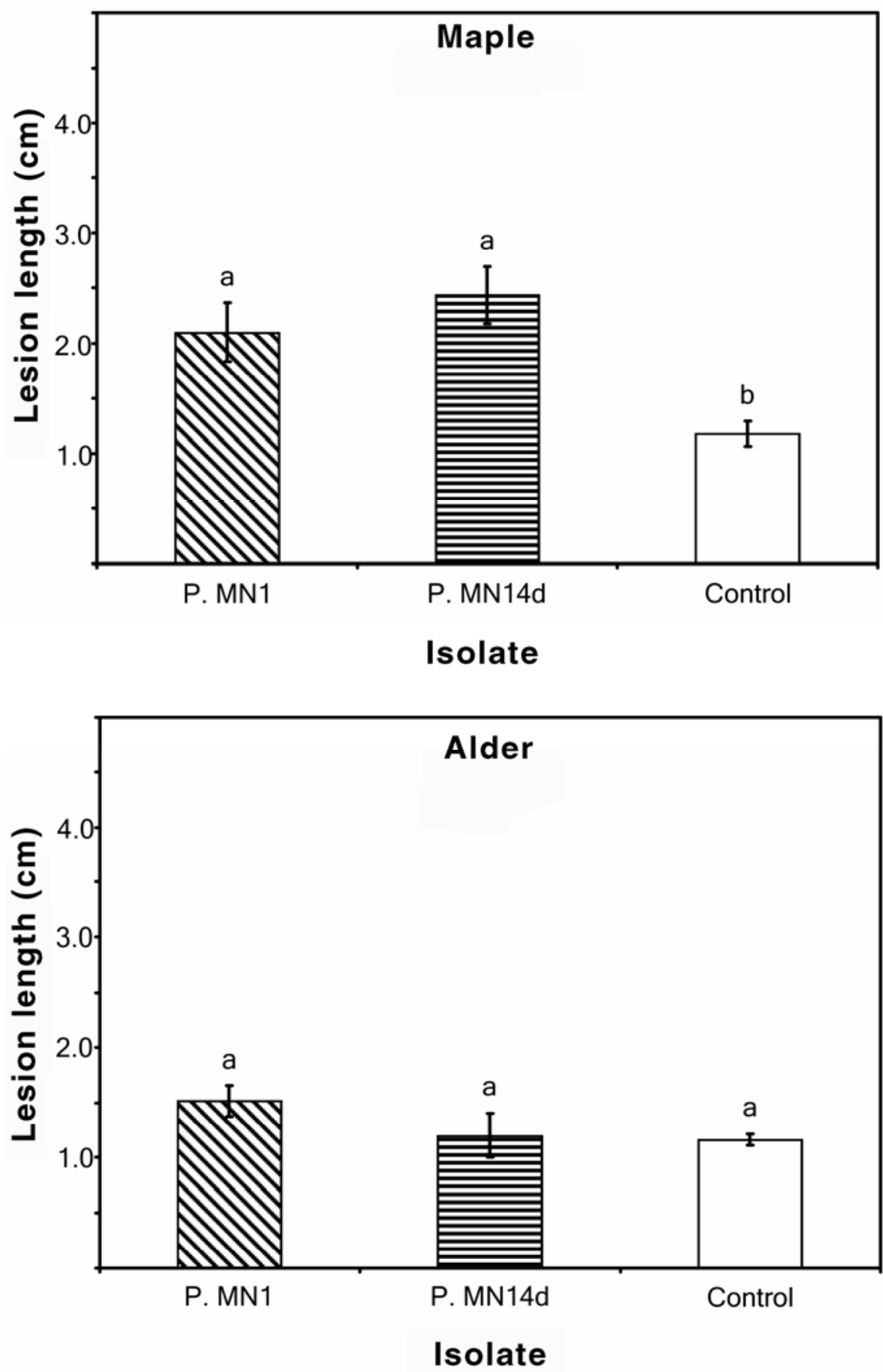

Fig. 2. Mean stem lesion lengths caused by Phytophthora sp. MN1 (P. MN1) and Phytophthora sp. MN14d (P. MN14d) and control mean wound lengths on Norway maple and European alder. Bars represent standard errors, and different letters represent significant differences $(P<0.05)$, indicated by Tukey's studentized range (highly significant difference) test, within each host experiment.

onstrated by inoculated trees having significantly longer lesion lengths than control wound lengths. P. cambivora previously has been shown as a pathogen of Malus domestica (9). Phytophthora sp. MN14d did not cause disease on European alder leaves or stems. This may indicate that it is not the same species as $P$. alni, because $P$. alni causes extensive disease on alder in Europe (11).

Unlike Phytophthora sp. MN14d, the ITS rDNA sequence of isolate Phytophthora sp. MN1 is different from that of any described Phytophthora spp. (20). This genicity on Snowdrift crabapple leaf tissue. However, we were able to demonstrate its potential pathogenicity on stem tissue of Snowdrift crabapple and on stem tissue of bur and red oak, Norway maple, and European alder, as well as on leaf tissue of four other woody ornamental plants. Although disease severity caused by Phytophthora sp. MN1 was not as great as that caused by other Phytophthora spp., it is a pathogen of unknown origin with an unknown host range and, therefore, should be of concern to growers and regulatory agencies.

The host plants used in this study that proved resistant to Phytophthora spp. may be examples of plants showing nonhost resistance. Alternatively, these plant species may not be susceptible to Phytophthora spp. at a specific growth stage, or they may be susceptible but show tissue-specific susceptibility. If inoculations were performed on plant roots instead of stems and leaves, results may have differed. Another noteworthy consideration is that zoospore concentration used for the nonwound inoculations may have been too low to cause noticeable disease symptoms in the plant dip experiments. Hansen et al. (12) demonstrated that four of five plant species tested exhibited significant increases in necrosis at higher Phytophthora zoospore doses. They also showed that younger leaves were more susceptible to infection by Phytophthora spp. than older leaves, which could explain why the Taxus $\times$ media plants in our study did not show disease symptoms from any of the Phytophthora spp. used. The plant dip inoculation method was chosen for these experiments because it approximated natural infection more closely than other common inoculation methods (12).

The results presented indicate that $P h y$ tophthora spp. isolated from woody plants in nurseries pose a disease threat to other plants commonly found in the landscape of the North Central region of the United States. This report expands knowledge of the potential host range for several newly described and undescribed Phytophthora spp., such as $P$. hedraiandra, Phytophthora taxon Pgchlamydo, Phytophthora sp. MN14d, and Phytophthora sp. MN1. For ornamental plants that are highly susceptible to Phytophthora spp., such as common lilac and fragrant sumac, selecting and propagating Phytophthora-resistant cultivars would benefit ornamental producers greatly. In addition, the unique ecological characteristics of Phytophthora sp. MN1 and Phytophthora sp. MN14d need to be elucidated and their appropriate taxonomic placement determined.

\section{ACKNOWLEDGMENTS}

Funding was provided by the University of Minnesota Rapid Agricultural Response Funds. We thank D. Zlesak and J. Smith for their assistance on this project and Bailey Nurseries, Inc. and the Minnesota Department of Natural Resources for supplying plants used in these experiments. 



Fig. 3. Mean stem lesion lengths caused by Phytophthora hedraiandra ( $P$. hed.), Phytophthora sp. MN1 (P. MN1), and Phytophthora sp. MN14d (P. MN14d) and control mean wound lengths on 'Snowdrift' crabapples from the $\mathbf{A}$, first and $\mathbf{B}$, second trials. Bars represent standard errors, and different letters represent significant differences $(P<0.05)$, indicated by Tukey's studentized range (highly significant difference) test, within each experimental trial.

\section{LITERATURE CITED}

1. Belisario, A., Gilli, G., and Maccaroni, M. 2006. First report of Phytophthora hedraiandra on Viburnum tinus in Italy. Plant Pathol. 55:573.

2. Brasier, C. M., Cooke, D. E. L., and Duncan, J. M. 1999. Origin of a new Phytophthora pathogen through interspecific hybridization. Proc. Natl. Acad. Sci. USA 96:5878-5883.

3. Brasier, C. M., Cooke, D. E. L., Duncan, J. M., and Hansen, E. M. 2003. Multiple new pheno- typic taxa from trees and riparian ecosystems in Phytophthora gonapodyides-P. megasperma ITS clade 6, which tend to be high-temperature tolerant and either inbreeding or sterile. Mycol. Res. 107:277-290.

4. Brasier, C. M., Hamm, P. B., and Hansen E. M. 1993. Cultural characters, protein patterns and unusual mating behavior of Phytophthora gonapodyides isolates from Britain and North America. Mycol. Res. 97:1287-1298.

5. Brasier, C. M., Kirk, S. A., Delcan, J., Cooke,
D. E. L., Jung, T., and Man In't Veld, W. A. 2004. Phytophthora alni sp. nov. and its variants: designation of emerging heteroploid hybrid pathogens spreading on Alnus trees. Mycol. Res. 108:1172-1184.

6. Cunnington, J. H., Jones, R. H., de Alwis, S., and Minchinton, E. J. 2006. Two new Phytophthora records for Australia. Australas. Plant Pathol. 35:383-384.

7. De Cock, A. W. A. M., and Lévesque, C. A. 2004. New species of Pythium and Phytophthora. Stud. Mycol. 50:481-487.

8. Erwin, D. C., and Ribeiro, O. K. 1996. Phytophthora Diseases Worldwide. The American Phytopathological Society, St. Paul, MN.

9. Farr, D. F., Bill, G. F, Chamuris, G. P., and Rossman, A. Y. 1989. Fungi on Plants and Plant Products in the United States. American Phytopathological Society, St. Paul, MN

10. Ferguson, A. J., and Jeffers, S. N. 1999. Detecting multiple species of Phytophthora in container mixes from ornamental crop nurseries. Plant Dis. 83:1129-1136.

11. Gibbs, J. N. 1995. Phytophthora root disease of alder in Britain. EPPO Bull. 25:661-664.

12. Hansen, E. M., Parke, J. L., and Sutton, W. 2005. Susceptibility of Oregon forest trees and shrubs to Phytophthora ramorum: a comparison of artificial inoculation and natural infection. Plant Dis. 89:63-70.

13. Hansen, E. M., Reeser, P., Davidson, J. N. Garbelotto, M., Ivors, K., Douhan, L., and Rizzo, D. M. 2003. Phytophthora nemorosa, a new species causing cankers and leaf blight of forest trees in California and Oregon, USA. Mycotaxon 88:129-138.

14. Jeffers, S. N., and Aldwinckle, H. S. 1987. Enhancing detection of Phytophthora cactorum in naturally infested soil. Phytopathology $77: 1475-1482$.

15. Jeffers, S. N., and Martin, S. B. 1986. Comparison of two media selective for Phytophthora and Pythium species. Plant Dis. 70:1038-1043.

16. Jung, T., and Blaschke, M. 2004. Phytophthora root and collar rot of alders in Bavaria: distribution, modes of spread and possible management strategies. Plant Pathol. 53:197-208.

17. Linderman, R. G., Davis, E. A., and Marlow, J. L. 2006. Response of selected nursery crop plants to inoculation with isolates of Phytophthora ramorum and other Phytophthora species. HortTechnology 16:216-224.

18. MacDonald, J. D., Ali-Shtayeh, M. S., Kabashima, J., and Stites, J. 1994. Occurrence of Phytophthora species in recirculated nursery irrigation effluents. Plant Dis. 78:607-611.

19. Moralejo, E., Belbahri, L., Calmin, G., Lefort, F., García, J. A., and Descals, E. 2006. First report of Phytophthora hedraiandra on Viburnum tinus in Spain. Plant Pathol. 55:574.

20. Schwingle, B. W., Smith, J. A., and Blanchette, R. A. 2007. Phytophthora species associated with diseased woody ornamentals in Minnesota nurseries. Plant Dis. 91:97-102.

21. Schwingle, B. W., Smith, J. A., Blanchette, R. A., Gould, S., Blanchette, B. L., Pokorny, J. and Cohen, S. D. 2006. First report of dieback and leaf lesions on Rhododendron sp. caused by Phytophthora hedraiandra in the United States. Plant Dis. 90:109.

22. Werres, S., Marwitz, R., Man In't Veld, W. A., De Cock, A. W. A. M., Bonants, P. J. M., De Weerdt, M., Themann, K., Ilieva, E., and Baayen, R.P. 2001. Phytophthora ramorum sp. nov., a new pathogen on Rhododendron and Viburnum. Mycol. Res. 105:1155-1165. 